\title{
Wildlife and spiritual knowledge at the edge of protected areas: raising another voice in conservation
}

Sarah Bortolamiol1,2,3,4,5*; Sabrina Krief1,3; Colin A. Chapman ${ }^{5}$; Wilson Kagoro ${ }^{6}$; Andrew Seguya ${ }^{6}$; Marianne Cohen ${ }^{7}$

\begin{abstract}
International guidelines recommend the integration of local communities within protected areas management as a means to improve conservation efforts. However, local management plans rarely consider communities knowledge about wildlife and their traditions to promote biodiversity conservation. In the Sebitoli area of Kibale National Park, Uganda, the contact of local communities with wildlife has been strictly limited at least since the establishment of the park in 1993. The park has not develop programs, outside of touristic sites, to promote local traditions, knowledge, and beliefs in order to link neighboring community members to nature. To investigate such links, we used a combination of semi-directed interviews and participative observations $(\mathrm{N}=31)$ with three communities. While human and wildlife territories are legally disjointed, results show that traditional wildlife and spiritual related knowledge trespasses them and the contact with nature is maintained though practice, culture, and imagination. More than $66 \%$ of the people we interviewed have wild animals as totems, and continue to use plants to medicate, cook, or build. Five spirits structure human-wildlife relationships at specific sacred sites. However, this knowledge varies as a function of the location of local communities and the sacred sites. A better integration of local wildlife-friendly knowledge into management plans may revive communities' connectedness to nature, motivate conservation behaviors, and promote biodiversity conservation.
\end{abstract}

Keywords: Chimpanzee; Kibale National Park; Local Communities; Spirits; Totems; Uganda; Wildlife

\footnotetext{
1 Sebitoli Chimpanzee Project (SCP), Great Apes Conservation Project (GACP), Sebitoli Station, Kibale National Park, Uganda

2 UMR 7533 Laboratoire Dynamiques Sociales et Recomposition des Espaces - Université Paris Diderot (Sorbonne Paris Cité), 200 avenue de la République, Nanterre Cedex 92001, France

${ }^{3}$ UMR 7206 Eco-Anthropologie et Ethnobiologie (MNHN/CNRS/Paris Diderot), 17 place du Trocadéro, Paris 75016, France

${ }^{4}$ Department of Geography, McGill University, 805 Sherbrooke street West, Montreal H3A 0B9, Canada

${ }^{5}$ Department of Anthropology, McGill University, 3460 McTavish street, Montreal H3A 1X9, Canada

6 Uganda Wildlife Authority, P.O. Box 3530, Kampala, Uganda

7 UMR 8185 Espaces, Nature, Culture (Sorbonne Université), Maison de la Recherche, 28 rue Serpente, Paris 75005, France

* Corresponding author. $\square$ E-mail address: SB (bortolamiol.sarah@gmail.com), SK (sabrina.krief@mnhn.fr), CAC (colin.chapman.research@gmail.com),WK (wilson.kagoro@ugandawildlife.org), AS (seguya@gmail.com), MC (marianne.cohen@paris-sorbonne.fr)
} 


\section{INTRODUCTION}

African protected areas (PAs) are mainly administered by non-governmental organizations (NGOs) or governmental departments, and local communities are only remotely involved in the writing of conservation management plans (Bennett et al. 2017). Success in national parks conservation has been suggested to be linked to education, awareness, and outreach programs to the communities neighbouring parks (Muhumuza and Balkwill 2013) or promotion of tourism activities (Archabald and Naughton-Treves 2001). However, Mugisha and Jacobson (2004) showed that conservation successes did not differ between Ugandan PAs with and without community-based conservation programs.

Traditional societies often have extensive biodiversity and ecological knowledge and maintain a deep connection to nature (Descola 2005; Friedberg 1997; Gadgil et al. 1993; Kohn 2013) through social and religious values, which were previously strong enough to make people obey environmental regulations. For example, clans, totems, and taboos played a significant role in biodiversity conservation by restricting human access to some places or species (Gorjestani 2004) through a variety of norms, practices, and beliefs (Attuquayefio and Gyampoh 2010; Dagba et al. 2013; Friedberg 2014; Ghanashyam Niroula and Singh 2015; Holmes et al. 2017; Infield 2001; Klepeis et al. 2016; Koponen 1988; Rim-Rukeh et al. 2013). Also, taboos often protect sacred groves which results in the protection of plants (Mgumia and Oba 2003); forest loss is less important in forest considered sacred (Byers et al. 2001); and hunting taboos allow wildlife population to increase (Saj et al. 2006). As a result, wildlife species that are regarded as sacred prosper (Dagba et al. 2013) and are often denser in areas where they were protected by traditional knowledge (Ntiamoa-Baidu 2008).

As the world's biodiversity loss is increasing (Ceballos et al. 2017), it is important to provide additional means to reduce threats. This is particularly the case at the highly populated edges of PAs, where wild plant and animal species collection is restricted or prohibited, as this may increase a cultural or psychological distance with wildlife, while people are suffering from wildlife's damage on their property, such as crop feeding. In this context, conservation programs should consider including positive local values and wildlife beliefs to reinforce the connection between people and nature to promote positive conservation behavior (Tam et al. 2013; Zylstra et al. 2014).

Here, we focus on Kibale National Park, Uganda (hereafter Kibale) where local communities' perception of the park became negative (MacKenzie et al. 2017). People's perspective is a function of historical management rules; wild animals damaging the crops (Bortolamiol et al. 2017; MacKenzie and Ahabyona 2012), a prohibition of local communities to enter the park and use its resources, and a concept of nature as a marketable good (i.e., tourism). This negative perception is made worse as the park's management of revenue sharing programs does not directly benefit the individuals suffering from wild animals' eating their crops, human injuries, and loss of property. Tourism, especially the one focusing on primates, is the second most important income earner of Uganda (Mackay and Campbell 2012; Republic of Uganda 2012; Uganda Vision 2040 2013). Kibale is a hotspot for primate tourism and was recently recognized the primate capital of Africa by safari circles ${ }^{1}$, and the main 
attraction is chimpanzee (Pan troglodytes schweinfurthii) vision tourism (Kagoro unpublished data). Tourism generates most of Kibale's revenue. Within local communities, chimpanzees are generally known to show "respect" towards people (by their discretion), while they are also "dangerous" (Hill and Webber 2010).

Sebitoli area, the northern section of Kibale $\left(25 \mathrm{~km}^{2}\right.$, Figure 1$)$ is embedded in an anthropogenic landscape (large tea, plantain, and eucalyptus plantations, small gardens, tarmac road). Here chimpanzee density is relatively high (Bortolamiol et al. 2016). To protect endangered chimpanzees (Appendix I CITES, Endangered on the IUCN red list) and their forest ecosystem, a Uganda Wildlife Authority (UWA) camp hosting rangers and eco-tourists is located near the village of Sebitoli. In the area, ecotourism consists in bird watching and nature walks, but primate watching is not developed. However, scientific research on chimpanzee ecology has been carried out since 2008 (Sebitoli Chimpanzee Project SCP).

Here we investigate if a positive relationship remains between local communities and the forest in Sebitoli area that could promote human-wildlife relationships, and help both human development and nature conservation. If so, we explore if its persistence expressed through four ways: 1) local communities' memory of wildlife related knowledge (plant and animal species); 2) cultural traditions, specifically clans and totems, and 3) spiritual beliefs about the forest that both link humans to wildlife; and 4) people's locations where inhabitants living near the park and far from modern infrastructures have a more diverse and vivid memory about wildlife.
We first provide historical background of the area since the arrival of British administrators to understand how local communities have been gradually distanced from wildlife and its management. Second, we carry qualitative, quantitative, and geographical analysis, including georeferenced inquiries and mapping, to analyze the above four points. Finally, we consider the importance of these links for conservation in this and other regions.

\section{MATERIAL AND METHODS}

\section{Study area}

Kibale's primate biomass is one of the highest in the world (Chapman and Lambert 2000; Chapman et al. 2018) and the park hosts a number of endangered species, including chimpanzees and elephants (Loxodonta africana). Outside Kibale there are up to 335 people $/ \mathrm{km}^{2}$ inhabiting a five kilometers buffer zone (Hartter 2010) dedicated to agriculture: local communities grow crops on small farms and some people work in large tea plantations, a large part of this labor force (40 to $60 \%$ ) being from districts other than those neighbouring the park or even from outside Uganda (Mbale and Ogwal 2015). Within this zone, human density is growing faster than employment opportunities and local communities are disappointed that the number of people employed by the PA did not increase, as much as the number of researchers and tourists (MacKenzie et al. 2017). 


\section{Kibale culture and history of biodiversity management}

Kibale is located in the Tooro kingdom and local communities are composed of two major ethnic groups: Batooro and Bakiga. Bakiga are fewer and arrived in the region later than Batooro, primarily in the 1950s, but they have similar social system and beliefs (Hartter et al. 2015). The roots of both groups are linked to the Cwezi dynasty (ancestral gods) who reigned over the Great Lake region and had mystical powers, such as control over rain, hunting, and human fertility (Chrétien 1985; Doyle 2007; Steinhart 1977). People in the region remember vivid narratives about these ancestral gods (Steinhart 2011). Also, clans (a collective of people who descend from the same distant ancestor; Beattie 1971; Roscoe 1968) have a central role in social and environmental interactions in the area. Each clan has one to several totems - an animal, a plant and/or an object - that clan members must respect and not kill or harm because of its links to a clan's ancestor (taboo).

When the Imperial British East African Company arrived in the area (1891), it supported Tooro against Bunyoro kingdom and British were granted powers over Batooro resources. It institutionalized biodiversity management and changed the established hierarchical system (Johnstone and Kasagama 1906; Kasagama and Lugard 1891; Naughton-Treves 1999; Toro agreement 1900). Hunting rules were defined (1906) distinguishing noble animals elephants - that only an elite could hunt from vermin - lions, leopards, hyenas, bush pigs, vervets, baboons - that everyone could hunt (Graham 1973). In the mid-1920s, game reserves were established to control dangerous wild animals threatening humans, crops, and cattle (Brooks and Buss 1962;
Morris 1978), but wildlife damages to crops were so problematic in the 1960 s that elephants were killed en masse. Also, Kibale Forest Reserve was commercially logged at that time, especially the Sebitoli area where a saw-mill was operating (Struhsaker 1997).

In the 1970s, eight years of Idi Amin dictatorship and starvation seriously impacted wildlife (De Merode et al. 2007; Hamilton 1984). In Tooro, elephants, buffaloes, hippopotamus were decimated so Idi Amin forbid all types of hunting (GDA 1979 cited in Naughton-Treves 1999). In the 1970-80s, settlers moved into the south of Kibale and cleared approximately $70 \mathrm{~km}^{2}$ of forest (MISR 1989; van Orsdol 1986). When the current president Yoweri Museveni came to power (1986), the Ugandan government again started to enforce regulation with respect to wildlife and biodiversity conservation. The population that moved into the south were expelled outside the Game Reserve and in 1993 the area became a national park.

When the area changed designation from a Forest and Game Reserve to a National Park $\left(795 \mathrm{~km}^{2}\right)$, it was placed under the management of the UWA, itself under the Tourism, Wildlife and Antiquities Ministry. The Uganda Wildlife Act (Republic of Uganda 1996) regulates the uses and practices towards protected spaces and species, and grantees local communities' a limited access to exploit wildlife sustainably under the supervision of UWA rangers (not recruited locally and regularly transferred) in resource use zones. UWA shares $20 \%$ of revenues generated by park entrance fees with local communities (UWA 2000) and the money is distributed to benefit community projects (Hartter and Ryan 2010). The funds are channeled through the district local government, where they are taxed. Both resources' access and revenue sharing 
programs successes are controversial and difficult to monitor, but UWA is seeking improvements (Adams and Infield 2003; MacKenzie 2012; Tumusiime and Vedeld 2012)

Semi directed interviews and participative observations with human communities

Georeferenced surveys were conducted in three villages: Kihingami, Nyakabingo, and Sebitoli, around Sebitoli area (JanuaryApril 2012, some information relative to clans and totems were confirmed in 2016) with the help of a local translator (Figure 1). This sample was designed to be in the close vicinity of the park and respondents were selected according to the distance between their home and the park's edge, their loss due to crop feeding (MacKenzie 2012), and proximity to landscape features (Table 1): Sebitoli village is the closest village to the park, the UWA station and the asphalt road and experiences medium losses due to crop feeding; Kihingami is located further from the park, the tarmac road, and UWA station than
Sebitoli village and experiences high losses due to crop feeding; Nyakabingo is located closer to the park, but further to the road and UWA station than Kihingami and experiences medium losses due to crop feeding.

Our objectives were presented to village chiefs who directed us to volunteer informants. Participants were ensured of anonymity in an informed consent form and the research followed the guidelines of the Declaration of Helsinki and Tokyo for humans, and complied with a Memorandum of Understanding [MoU] for research and conservation in Kibale National Park between Museum national d'Histoire naturelle, Uganda Wildlife Authority and Makerere University (SJ445-12).

Georeferenced semi-directed interviews and participative observations were conducted simultaneously with 30 participants (10/village) at the respondents' home during their daily activities (Bortolamiol 2014). For brevity, we cite the information as followed: " $\mathrm{N}_{\mathrm{i}}=30$ " designates the population interviewed in the three villages; " $N_{\text {spirits }}=31$ "

Table 1. Spatial characteristics of the survey area

\begin{tabular}{|c|c|c|c|}
\hline & Kihingami & Nyakabingo & Sebitoli \\
\hline $\begin{array}{c}\text { Distance from households' residence } \\
\text { to the closest park edge }(\mathrm{m})\end{array}$ & $142-770$ & $11-183$ & $45-938$ \\
\hline $\begin{array}{l}\text { Distance from village centroid to the } \\
\text { closest road }(\mathrm{m})\end{array}$ & 525 & 7000 & 0 \\
\hline $\begin{array}{l}\text { Distance from village centroid to UWA } \\
\text { station }(\mathrm{m})\end{array}$ & 1340 & 4521 & 447 \\
\hline $\begin{array}{l}\text { Distance from village centroid to the } \\
\text { closest tea plantation }(\mathrm{m})\end{array}$ & 10 & 320 & 195 \\
\hline $\begin{array}{l}\text { Distance from village centroid to the } \\
\text { closest tea factory }(m)\end{array}$ & 2084 & 3816 & 560 \\
\hline $\begin{array}{l}\text { Intensity of crop feeding loss (adapted } \\
\text { from MacKenzie 2012) }\end{array}$ & High & Medium & Medium \\
\hline $\begin{array}{l}\text { UWA compensation (apart from } \\
\text { revenue sharing; MacKenzie 2012) }\end{array}$ & $\begin{array}{l}\text { Elephant trench } \\
\text { and school }\end{array}$ & $\begin{array}{l}\text { Elephant trench, } \\
\text { school and bridge }\end{array}$ & $\begin{array}{l}\text { Elephant trench } \\
\text { and school }\end{array}$ \\
\hline Approximate area $\left(\mathrm{km}^{2}\right)$ & 0.65 & 0.25 & 0.3 \\
\hline Store number in the village & 7 & 0 & 14 \\
\hline
\end{tabular}


the people interviewed in the three villages and a supplementary conversation about specific tree spirits. None of the 12 women and 18 men we interviewed were employed by the park and their main activity was agriculture. They were aged between 17 and 74 years old (mean 40 years old) and apart a mother and her daughter, none of them were related.

All villagers were asked about their tribe, clan, and totem, about plants they used in their daily activity, and wild animals they knew from the park. We used the excel FLAME 1.1 supplement (Pennec et al. 2012) to list the frequency and rank citation of animal species. We classified responses about animals in nine groups based on morphological/biological criteria (Table 2). Respondents used vernacular names to identify plant and animal species, which were later translated. When they did not know the species, they often cited the general taxa. As for questions related to beliefs about chimpanzees and spirits, respondents were asked two questions: "Do you know stories about chimpanzees/spirits in the area?" If respondents answer was "Yes" we would ask "Can you tell us more about these stories?" and if the answer was "No" we would move to another question. These two questions were open ended and led to a diversity of narratives that we compiled by themes. Finally, spirits locations - Ebiigasaigasa, Kaliisa, and Nyakakaikuru -, were mapped based on the village where respondents cited them, to verify the influence of geographical factors using GIS (Bortolamiol 2014; ArcGIS 10.2; Figure 1). The specific locations of some features (Rugamba, magical stones) were mapped thanks to respondents who brought interviewers to these specific locations.

We verified the relationships between wildlife related knowledge (plants, animals, spirits), social (tribe, totem) and geographical variables (households' residence distance to the park, villages' location; Add file 1). SPSS Statistics (IBM, version 24) was used to conduct parametric (Fisher exact test - several qualitative variables, Pearson correlation - two qualitative variables) and non-parametric tests (Mann-Whitney - a quantitative variable and two groups of qualitative variables, Kruskall-Wallis - quantitative variable and more than two groups of qualitative variables). The combination of such methods produced a qualitative analysis supported by a simple quantitative approach.

\section{RESULTS}

\section{Wildlife related knowledge: plants as useful resources and animals as abundant neighbours}

The people we interviewed use plant species for medicine $\left(\mathrm{N}_{\mathrm{i}}=22\right.$ respondents, 48 species), firewood $\left(\mathrm{N}_{\mathrm{i}}=22\right.$ respondents, 23 species), timber $\left(\mathrm{N}_{\mathrm{i}}=5\right.$ respondents, 16 species), and other uses $\left(\mathrm{N}_{\mathrm{i}}=10\right.$ respondents, 12 species; baskets, building, charcoal, fence, fertilizer, hygiene, planting trees, poultry, roof top). For medicine, Vernonia amygdalina $\left(\mathrm{N}_{\mathrm{i}}=13\right)$, Ocimum gratissimum $\left(\mathrm{N}_{\mathrm{i}}=8\right)$, and Bidens pilosa $\left(\mathrm{N}_{\mathrm{i}}=\right.$ 6) are mostly found in bushland, gardens, or forest edges. For firewood, respondents mostly used planted species, such as Eucalyptus sp. $\left(\mathrm{N}_{\mathrm{i}}=14\right)$, Bridelia micrantha $\left(\mathrm{N}_{\mathrm{i}}=6\right)$, and Sesbania sesban $\left(\mathrm{N}_{\mathrm{i}}=5\right.$; Add file 2).

Ethno-zoological knowledge was gathered by asking which animals lived in Kibale. Respondents cited 45 answers: 29 referred to distinct species and 16 to general taxa - monkeys, red monkeys 
(Cercopithecus ascanius or Procolobus rufomitratus), colobus monkeys ( $P$. rufomitratus or Colobus guereza), antelopes, wild pigs, wild rabbits, rats, squirrels, birds, butterflies, snakes, frogs, insects, small insects, millipedes, ants. Among nine morphological groups, primates $(\mathrm{N}=15)$ and ungulates ( $\mathrm{N}=11$; Table 2) had the highest diversity of species. Among the animal citations, gorillas, de Brazza monkeys, patas monkeys, cranes, goats, and rhinoceros are not present in Kibale. Hippopotamus are found $40 \mathrm{~km}$ to the south of the Sebitoli area. The presence of lion or leopard in the area is extremely rare (lions do not reside in Kibale and leopard are very rare - Chapman unpublished data).

Elephant $(93.1 \%$, citation rank=1.6), chimpanzee $(89.7 \%$, citation rank $=4.4)$, and baboon $(86.2 \%$, citation rank $=2.3)$ were the most cited taxa (2/3 of the sample). The morphological group that was cited more often was primates (120/218 citations, 55\%).

\section{Human-wildlife relationships: a distended link with chimpanzees}

All villagers stated that baboons and chimpanzees caused less damages than elephants. The most mentioned physical trait of chimpanzees was their resemblance to humans $\left(N_{i}=17\right)$ and the fact that they have no tail $\left(\mathrm{N}_{\mathrm{i}}=7\right)$ unlike other primates. Chimpanzees are reported to be more selective than elephants and baboons in the crops they feed, preferring maize and sugarcane $\left(\mathrm{N}_{\mathrm{i}}=9\right)$. Villagers noted that some chimpanzees play a sentinel role, while others feed on crops $\left(N_{i}=4\right.$; Add file 3$)$ and often chimpanzees wait until humans are not in their field before entering it $\left(\mathrm{N}_{\mathrm{i}}=5\right)$ or wait until the night $\left(\mathrm{N}_{\mathrm{i}}=4\right.$; verified with infrared cameras - Krief et al. 2014). Chimpanzees are easy to scare away because they are fearful, but three women stated they were at risk of sexual abuse by chimpanzees and two stated there was a risk of chimpanzees kidnapping their baby.

A mother and her daughter had a narrative about chimpanzees in Kihingami and stated that a long time ago humans fled to the forest to avoid paying taxes and transformed into chimpanzees over generations because they lived in the forest (Add file 4).

\section{Traditions linking humans to wildlife: wild and domestic totems}

The people interviewed were primarily Batooro $\left(70 \% ; \mathrm{N}_{\mathrm{i}}=21\right)$ and Bakiga $\left(20 \% ; \mathrm{N}_{\mathrm{i}}=\right.$ 6 ), but immigrants from Rwanda were also included $\left(10 \% ; \mathrm{N}_{\mathrm{i}}=3\right)$. Each village had a similar number of clans (9 or 10; 13 different clans in total; Table 3). Clans' membership influences social relationships and members of the same clan often help each other in times of financial needs "when someone is sick, they help, when someone dies they help, when someone needs to go to school they help". However, nowadays clans intermarry while it is "not wise to mix-up because of inbreeding risks and general confusions with ancestral clans' rules".

Each respondent is a clan member and has a totem, with a duty to protect $\left(\mathrm{N}_{\mathrm{i}}=21\right)$ and not to eat or hurt his or her totem $\left(\mathrm{N}_{\mathrm{i}}=\right.$ 20). Eight out of 13 totems were wild animals (Table 3), but some of these species are not now in Sebitoli (lion, leopard, and hippopotamus). Two-third of respondents have wild animals as totems $\left(\mathrm{N}_{\mathrm{i}}=20\right)$, and one-third have domestic animals, crops, or object as totems $\left(\mathrm{N}_{\mathrm{i}}=10\right)$.

\section{Beliefs linking humans to wildlife}

Out of 31 people asked about spiritual 
Ethnobio Conserv 7:12

Table 2. General knowledge about wild animals

\begin{tabular}{|c|c|c|c|c|}
\hline Species and general taxa & $\begin{array}{l}\text { Occurrence } \\
\left(\mathrm{N}_{\mathrm{i}}=30\right)\end{array}$ & Frequency $(\%)$ & $\begin{array}{c}\text { Rank } \\
\text { citation }\end{array}$ & $\begin{array}{l}\text { Presence in Kibale National } \\
\text { Park according to scientists }\end{array}$ \\
\hline \multicolumn{5}{|c|}{ Large mammals } \\
\hline Elephant (Loxodonta africana) & 27 & 93.1 & 1.6 & Yes \\
\hline Lion (Panthera leo) & 3 & 10.3 & 7 & $\begin{array}{c}\text { No (occasional visits from } \\
\text { neighbouring Queen Elizabeth } \\
\text { National Park) }\end{array}$ \\
\hline \multicolumn{5}{|c|}{ Primates } \\
\hline Chimpanzee (Pan troglodytes schweinfurthii) & 26 & 89.7 & 4.4 & \multirow{7}{*}{ Yes } \\
\hline Baboon (Papio anubis) & 25 & 86.2 & 2.3 & \\
\hline Monkey (general) & 21 & 72.4 & 4.2 & \\
\hline Black and white colobus (Colobus guereza) & 17 & 58.6 & 6.5 & \\
\hline $\begin{array}{l}\text { Red tailed monkey (Cercopithecus ascanius } \\
\text { schmidti) }\end{array}$ & 11 & 37.9 & 6.9 & \\
\hline Red colobus (Procolobus rufomitratus) & 6 & 20.7 & 7.2 & \\
\hline Vervet (Chlorocebus pygerythrus) & 3 & 10.3 & 5 & \\
\hline Gorilla (Gorilla sp.) & 2 & 6.9 & 3.5 & No \\
\hline L' Hoest monkey (Cercopithecus Ihoesti) & 2 & 6.9 & 12 & \multirow{2}{*}{ Yes } \\
\hline Mangabey (Cercocebus albigena) & 2 & 6.9 & 10.5 & \\
\hline Patas monkey (Erythrocebus patas) & 1 & 3.5 & 13 & \multirow{2}{*}{ No } \\
\hline De Brazza monkey (Cercopithecus neglectus) & 1 & 3.5 & 17 & \\
\hline Blue monkey (Cercopithecus mitis) & 1 & 3.5 & 19 & \multirow{3}{*}{ Yes } \\
\hline Red monkey (general) & 1 & 3.5 & 4 & \\
\hline Colobus (general) & 1 & 3.5 & 4 & \\
\hline \multicolumn{5}{|c|}{ Birds } \\
\hline Bird (general) & 6 & 20.7 & 8.3 & \multirow{2}{*}{ Yes } \\
\hline Owl (Strigiformes sp.) & 1 & 3.5 & 6 & \\
\hline Crane (Balearica regulorum) & 1 & 3.5 & 9 & $\begin{array}{l}\text { No (typically outside but can be } \\
\text { found to the south of the park) }\end{array}$ \\
\hline $\begin{array}{c}\text { Guinea fowl (Numida meleagris, } \\
\text { Guttera pucherani) }\end{array}$ & 1 & 3.5 & 3 & 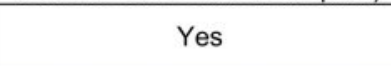 \\
\hline \multicolumn{5}{|l|}{ 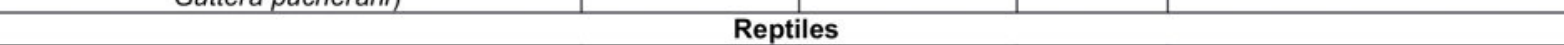 } \\
\hline Snake (general) & 4 & 13.8 & 5.3 & Yes \\
\hline \multicolumn{5}{|c|}{ Ungulates } \\
\hline Wild pig (general) & 9 & 31 & 6.3 & \multirow{8}{*}{ Yes } \\
\hline Bushbuck (Tragelaphus scriptus) & 5 & 17.2 & 7 & \\
\hline Buffalo (Syncerus caffer) & 5 & 17.2 & 7.4 & \\
\hline Blue duiker (Cephalophus monticola) & 4 & 13.8 & 8 & \\
\hline Antelopes (general) & 2 & 6.9 & 6 & \\
\hline $\begin{array}{l}\text { Giant forest hog (Hylochoerus } \\
\text { meinertzhageni) }\end{array}$ & 2 & 6.9 & 7.5 & \\
\hline Warthog (Phacochoerus aethiopicus) & 2 & 6.9 & 6 & \\
\hline Red duiker (Cephalophus harveyi) & 2 & 6.9 & 6.5 & \\
\hline Rhinoceros (Diceros biscornis) & 1 & 3.5 & 5 & No \\
\hline Hippopotamus (Hippopotamus amphibius) & 1 & 3.5 & 9 & $\begin{array}{l}\text { Yes (rare, not in respondents' } \\
\text { daily environment) }\end{array}$ \\
\hline Goat (Capra sp.) & 1 & 3.5 & 13 & No \\
\hline \multicolumn{5}{|c|}{ Small ground mammals } \\
\hline Rat (general) & 8 & 27.6 & 5.4 & \multirow{6}{*}{ Yes } \\
\hline Squirrel (general) & 2 & 6.9 & 17 & \\
\hline Mongoose (Herpestidae sp.) & 2 & 6.9 & 6 & \\
\hline Wild rabbit (general) & 1 & 3.5 & 5 & \\
\hline Mouse (general) & 1 & 3.5 & 13 & \\
\hline Hedgehog (Atelerix sp.) & 1 & 3.5 & 12 & \\
\hline \multicolumn{5}{|c|}{ Insects } \\
\hline Insect (general) & 1 & 3.5 & 6 & \multirow{5}{*}{ Yes } \\
\hline Butterfly (general) & 1 & 3.5 & 6 & \\
\hline Millipedes (general) & 1 & 3.5 & 6 & \\
\hline Small insect (general) & 1 & 3.5 & 5 & \\
\hline Ant (general) & 1 & 3.5 & 4 & \\
\hline \multicolumn{5}{|c|}{ Amphibian } \\
\hline Frog (general) & 1 & 3.5 & 7 & Yes \\
\hline
\end{tabular}

Legend: Wild animal species cited by villagers from Kihingami, Nyakabingo and Sebitoli $\left(\mathrm{N}_{\mathrm{i}}=30\right)$ to be within Kibale National Park, Uganda. The information was classified by morphological/biological traits (NB: general taxa are underlined) 
Table 3. Respondents' tribes, clans and totems

\begin{tabular}{|c|c|c|c|c|c|c|c|c|}
\hline $\begin{array}{c}\text { Clan vernacular } \\
\text { name }\end{array}$ & $\begin{array}{c}\text { Totem } \\
\text { vernacular } \\
\text { name }\end{array}$ & $\begin{array}{l}\text { Totem } \\
\text { translation } \\
\text { name }\end{array}$ & $\begin{array}{l}\text { Kihingami } \\
\text { villagers }\end{array}$ & $\begin{array}{l}\text { Nyakabingo } \\
\text { villagers }\end{array}$ & $\begin{array}{c}\text { Sebitoli } \\
\text { villagers }\end{array}$ & Batooro & Bakiga & $\begin{array}{l}\text { Other } \\
\text { tribes }\end{array}$ \\
\hline \multicolumn{9}{|c|}{ Domestic animals $(\mathrm{N}=8 / 30)$} \\
\hline Abakurungo & Etimba & Cow & 0 & 2 & 1 & 2 & 1 & 0 \\
\hline Abasaigi & Nkira & Cow & 1 & 1 & 0 & 2 & 0 & 0 \\
\hline Abasita & Busito & Cow & 1 & 0 & 2 & 3 & 0 & 0 \\
\hline \multicolumn{9}{|c|}{ Wild animals $(\mathrm{N}=20 / 30)$} \\
\hline Abagaya & $\begin{array}{l}\text { Akateman- } \\
\text { konge }\end{array}$ & Bird & 0 & 1 & 0 & 0 & 0 & 1 \\
\hline Abagaya & Entale & Lion & 1 & 0 & 0 & 1 & 0 & 0 \\
\hline Abazigaba & Ngabi & Bushbuck & 0 & 2 & 0 & 0 & 2 & 0 \\
\hline Abazigaba & Ngo & Leopard & 0 & 1 & 1 & 1 & 1 & 0 \\
\hline Abaziraija & Ngabi & Bushbuck & 1 & 0 & 0 & 1 & 0 & 0 \\
\hline Abagweri & Ngabi & Bushbuck & 1 & 0 & 1 & 2 & 0 & 0 \\
\hline $\mathrm{NA}^{*}$ & Ngabi & Bushbuck & 0 & 1 & 0 & 1 & 0 & 0 \\
\hline Ababopi & Ekigangoro & Centipede & 0 & 0 & 1 & 1 & 0 & 0 \\
\hline Abaranzi & Ndaha & Guinea fowl & 0 & 0 & 1 & 1 & 0 & 0 \\
\hline Abagahe & Ensere & Hippopotamus & 1 & 1 & 0 & 1 & 0 & 1 \\
\hline Abahinda & Enkende & Monkey & 3 & 1 & 2 & 5 & 1 & 0 \\
\hline \multicolumn{9}{|c|}{ Crops and objects $(\mathrm{N}=2 / 30)$} \\
\hline Abanyonza & Ekyayaya & Banana & 1 & 0 & 0 & 1 & 0 & 0 \\
\hline Abasambo & Empindo & $\begin{array}{c}\text { Needle to make } \\
\text { baskets }\end{array}$ & 0 & 0 & 1 & 0 & 0 & 1 \\
\hline
\end{tabular}

Legend: Tribes, clans, and totems of respondents $\left(\mathrm{N}_{\mathrm{i}}=30\right)$ in Kihingami, Nyakabingo and Sebitoli villages $\left({ }^{*}\right.$ missing data) around Kibale National Park, Uganda

knowledge, 20 shared information; these people described two types of spirits: fixed and transient (Figure 1). All transient spirits navigate at the forest edge, some go within the forest and some stay outside, while fixed spirits are located along an anthropogenic element, the tarmac road. All spirits are met in particular areas linked to villagers' daily life (i.e., stones, trees, valleys, wetlands, forest edges), mostly at night, and can be associated to alcohol consumption (Add file $5)$.

\section{Rugamba and Engote trees: fixed spirits symbolizing nature's resistance to human activities}

The Rugamba tree (a Ficus saussaureana tree) was mentioned in eight interviews; one person living in Sebitoli village was identified by four of the people that we interviewed as being particularly knowledgeable about the tree because he/she used to visit the tree (Add file 6a). Rugamba is not a vernacular name for a tree species, but refers to a specific individual tree. The main respondent led us to the "remaining babies of the tree", located in the park, $20 \mathrm{~m}$ from the tarmac road $\left(\mathrm{N}_{\text {spirits }}=6\right)$ and/or by rivers $\left(\mathrm{N}_{\text {spirits }}=3\right)$. The original tree was cut $\left(\mathrm{N}_{\text {spirits }}=3\right)$ when the road was built by "Italian white men" $\left(\mathrm{N}_{\text {spirits }}=4\right)$, leaving sprouting stems $\left(\mathrm{N}_{\text {spirits }}=2\right.$; "There is a small one, inherited from the other one", "After three days, (...), a young one came out and was produced from that main big one. Up to now it is still there"). However, the sucker does not have the same powers as the original tree that was possessed by a spirit, could talk, and people would come to sacrifice to that tree $\left(\mathrm{N}_{\text {spirits }}=5\right)$. Three villagers said that the tree was talking while being cut but each informer had a different version of this speech (Add file 6a). 


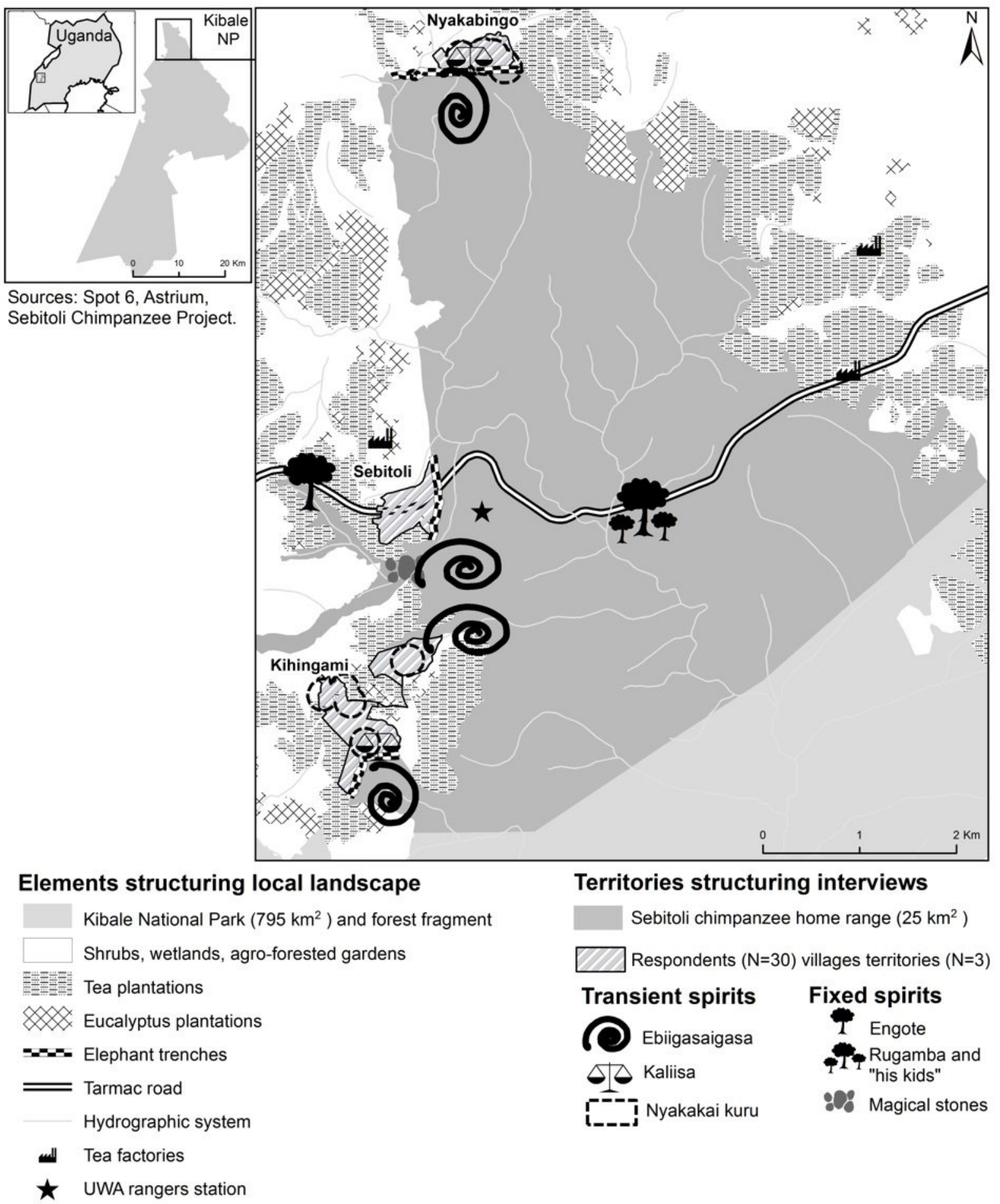

Figure 1. Locations of fixed and transient spirits within/around Sebitoli area (Kibale National Park, Uganda) according to respondents ( $\mathrm{N}_{\text {spirits }}=31$ ) from Kihingami, Nyakabingo and Sebitoli villages. 
The Engote tree (vernacular name for Prunus africana) was mentioned in two interviews (the same person identified in Sebitoli about Rugamba, and one person in Kihingami - Add file 6b, c). The story of Engote tree was less detailed, but resembles the one of Rugamba as the tree resisted to be cut by humans. However, its resistance continued after its death as respondents stated that the spirit inhabiting the tree revenged itself from being cut by killing eight people in a bus accident where the tree was originally located.

\section{Transient spirits}

Kaliisa, a forest hunter spirit $\left(\mathrm{N}_{\mathrm{i}}=3\right)$, was cited in 11 interviews. It is described to move with barking dogs $\left(\mathrm{N}_{\mathrm{i}}=3\right)$, crying $\left(\mathrm{N}_{\mathrm{i}}=1\right)$, difficult to observe $\left(\mathrm{N}_{\mathrm{i}}=1\right)$, and resembling a tall human $\left(\mathrm{N}_{\mathrm{i}}=2\right)$ or an animal $\left(\mathrm{N}_{\mathrm{i}}=1\right)$. The association between Kaliisa and sacrifice (offering animal parts to the spirit) was made in two interviews, but Kaliisa has been described more frequently as guarding and grazing cattle in pasture $\left(\mathrm{N}_{\mathrm{i}}=5\right)$. If hunters ask Kaliisa's permission to hunt in the forest, the spirit will watch the hunter's safety, as well as his cattle. Kaliisa is bridging the gap between the agricultural and forested worlds, watching cattle, humans and wild animals (Figure 1).

Ebiigasaigasa, the "carrier", was mentioned in 11 interviews. This spirit is of great height $\left(\mathrm{N}_{\mathrm{i}}=5\right)$, and shows a similarity with humans in general $\left(\mathrm{N}_{\mathrm{i}}=2\right)$ or "white people" in particular $\left(\mathrm{N}_{\mathrm{i}}=3\right)$. When it is moving, it is surrounded by light $\left(\mathrm{N}_{\mathrm{i}}=4\right)$. Ebiigasaigasa "kidnaps" a person it meets at the forest edge (Figure 1; $\mathrm{N}_{\mathrm{i}}=11$ ) and transports he/her "somewhere else" $\left(\mathrm{N}_{\mathrm{i}}=4\right)$ or inside the forest $\left(\mathrm{N}_{\mathrm{i}}=3\right)$. This spirit is associated with night encounters $\left(\mathrm{N}_{\mathrm{i}}=8\right)$ and particular places (stones $\mathrm{N}_{\mathrm{i}}=6$; mountain/hills
$N_{i}=2$; wetland/valleys $N_{i}=1$; water hole $N_{i}=1$ ). Three people mentioned that the risk of encountering Ebiigasaigasa increased with alcohol consumption and with the proximity to magical stones (Figure 1).

Nyakakaikuru, a "greedy" spirit mentioned in nine interviews, is encountered at night $\left(\mathrm{N}_{\mathrm{i}}=4\right)$. A third of the respondents mentioned that Nyakakaikuru is harmless as it only passes through land $\left(\mathrm{N}_{\mathrm{i}}=3\right)$. It comes at night and visits villagers' kitchens to find food. According to all interviews, each household leaves a dish full of food in the kitchen at night. If Nyakakaikuru comes and finds no food, it can destroy materials in the house.

During interviews, respondents $\left(\mathrm{N}_{\mathrm{i}}=4\right)$ stated that fixed and transient spirits were evils that no one still believe in. When respondents were asked why people no longer believed in them, they stated that belief in them disappeared when Christianity developed $\left(\mathrm{N}_{\mathrm{i}}=4\right)$ and with modernization $\left(\mathrm{N}_{\mathrm{i}}=3\right)$.

\section{Geographical and social variations of wildlife related knowledge and spiritual beliefs}

Statistically significant relationships between wildlife related knowledge, social and geographical factors are few (Add file 1). Batooro are over-represented in Kihingami, and under-represented in Nyakabingo $(p=$ 0.004 ) and they live further from the forest edge than Bakiga $(p=0.044$; mean $=327.3 \mathrm{~m}$ vs. $81.5 \mathrm{~m}$ ). A higher diversity of firewood species are cited in Nyakabingo $(p=0.036$; mean Sebitoli=1.3; Kihingami=2.8; Nyakabingo=3.3). Also, the number of timber species is higher for other tribes $(p=0.033$; mean=4.3), than Batooro $(m e a n=1)$ and Bakiga (mean=0.24). Villagers' residency influenced spiritual beliefs $(p=0.028)$ as most citations were obtained in Nyakabingo and 
Kihingami $\left(\mathrm{N}_{\mathrm{i}}=33\right)$, and the least in Sebitoli village $\left(\mathrm{N}_{\mathrm{i}}=5\right)$. Rugamba fixed spirit was mostly cited in Sebitoli village (5 out of 8; Figure 1). Kaliisa and Nyakakaikuru (respective $p=0.0006,0.037$ ) were mostly cited at Nyakabingo.

\section{DISCUSSION}

Although the local populations were largely excluded from biodiversity management around Kibale, wildlife related knowledge remains in the Sebitoli area through animals and plants' knowledge, culture (totems), spiritual beliefs (fixed, transients), but knowledge varies among villages. Wildlife related knowledge was not generally related to social and geographical factors. This could be due either to our sample size, a weakened link between humans and wildlife, and/or a relatively small quantity of wildlife related knowledge shared equally and independently from social or geographical characteristics. In Nyakabingo, the village with fewer facilities and shops and further from the tarmac road, there are more Bakiga (who live closer to the park in general), spirits' citations (especially transients), and species used for firewood. No social and geographical links are established with animal related knowledge, but wild animal remain the major totems of local populations.

\section{Wildlife related traditions and knowledge}

Villagers' identities include wild animal totems, which they have a duty to protect independently from their tribes' membership. Thus, totems may still play a significant role in biodiversity conservation, as evoked in our literature review. Villagers are aware of a diversity of wild animal species and besides approximations (general taxa, species that do not live in Kibale), the most frequently cited species (e.g., elephants, chimpanzees, baboons) are also the most frequent species coming out of the forest and feeding in gardens (MacKenzie 2012, MacKenzie and Ahabyona 2012). Other animal species occur in fields and houses (e.g., rats, squirrels, frogs, mongooses, goats, insects) or are hunted (ungulates, elephants, and small terrestrial mammals), an activity which is illegal. Also, wild plant species are still used by local communities in their daily activities (medicine, firewood, timber), but are likely found at the park's edges, in bushlands, or are being planted.

Legends and traditions related to animals are rare (or rarely mentioned), but chimpanzees are resembling humans, no matter respondents' tribe or location. We suggest that the narrative of local communities depicting a close affiliation between humans and chimpanzees implies four things: (1) chimpanzees are "descendants" of humans; (2) the way of life distinguishes humans from the great apes; (3) the fragility of the human condition, and their economic vulnerability; and (4) the forest seems to play a filtering role and reveals the discontinuity between the two species. This narrative is similar to others that refers to the bonobos in the Democratic Republic of Congo (Narat et al. 2015) and the chimpanzees in Republic of Congo (Köhler 2005), Nigeria (Nyanganji et al. 2010), and Guinea Bissau where local people said that chimpanzees were the species they would like to be if they were not human and they noticed a close resemblance between species in terms of morphology (face, feet) and behavior (gestures, bipedalism; Costa et al. 2013; Sousa et al. 2014).

Unlike the stories about wolf-children 
(Aroles 2007) and the fictional character of Mowglie (Kipling 1895), chimpanzees descending from humans never returned to their original environment, which has interesting conservation dimensions: the forest is today the territory of chimpanzees and not the "natural" territory of men, but their refuge in case of threat. Each species belongs to a specific area: the park is currently inhabited by chimpanzees and villages are inhabited by humans. Looking alike human, the chimpanzee is not usually consumed for its meat in Uganda (Peterson and Goodall 1993). However, one chimpanzee was recently hunted and killed near Sebitoli village (Krief unpublished data) which may reflect a detachment of traditions, or may have resulted because many workers come from other areas of Uganda or from neighbouring countries with different food taboos.

\section{A link with wildlife through spiritual beliefs}

Wild animals remain in villagers' knowledge about nature (totems, species diversity), but they are absent in spiritual beliefs which are mainly trees, minerals or human shaped. The power of nature (trespassing boundaries; seismic activities; thunder, rain, fire, etc., - Chapman et al. 1999; Krief and Brunois-Pasina 2017) is illustrated by transient spirits, but their representations are influenced by geographical features. For example, people living in villages beside the tarmac road have a less persistent perception of an intangible link with natural elements. Also, close proximity to facilities and the tarmac road facilitates contacts with tea workers and foreigners, and may promote loss of these links to nature.

Orally transmitted stories about spirits still exist and link humans with the wildlife of the park. Spirits symbolize the relationship between wild and human territories that are currently perceived by villagers as asymmetrical, since they are forbidden to enter Kibale without UWA permission (but they trespass it; Bortolamiol unpublished data), while spirits and wild animals have the "permission" to cross or make humans cross the forest edge for certain activities (e.g., crop feeding). This perceived asymmetry can lead people to feel left aside of conservation management (MacKenzie 2012) and may promote actions the park views as negative (e.g., poaching Bortolamiol unpublished data).

Narratives we collected about wildlife and spirits testify a complex relationship to foreign elements, such as fear of taxes and fear of "white man". When Christian missionaries arrived in Uganda, some cults were driven underground (Behrend 2011) but their positive and rehabilitating aspects could be used in conservation awareness programs (Rubongoya 2003). In Sebitoli area, modernization and development may participate in blurring traditional and wildlife knowledge as it was showed in Bolivia where plant use changes were more acute in villages close to market towns than in remote villages over time (Reyes-Garcia et al. 2013). This is why the weak influence of geographical distance (to infrastructures: roads, tea factories; fixed spirit etc.) is an indirect factor, suggesting the importance of acculturation.

\section{Changing scale: promoting regional conservation efforts through local ecological knowledge}

Positive aspects of totemic and spiritual beliefs are not currently integrated in biodiversity conservation programs within 
local communities around Kibale, because there was no clear evidence about them. However, as the world faces new animal extinction (Ceballos et al. 2017) besides the international conservation programs that were set the last 30 years, scientists "urge the conservation community to move beyond superficial engagement with the conservation of social sciences" (Bennett et al. 2017). They also urge for a better application of international guidelines (integration of local communities' knowledge) into local management plans. Indeed, informal institutions (Rim-Rukeh et al. 2013), such as totemic and spiritual systems, can drive human behaviors and self-connectedness to nature (Schultz 2011; Tam et al. 2013; Zelenski and Nisbet 2014). Then, they can influence positively humanwildlife relationships and people's will to participate in nature conservation. Learning from and using local communities' traditional knowledge (such as why/which species and places are protected in the traditions) may not only be a tool to help build the muchneeded consensus between conservationists and local people, but it can also give communities a sense of ownership of wildlife management projects (Berkes 2004).

Historical, social, and geographical factors contribute to the connection of local communities with nature and should be considered alongside species, places, and ecological knowledge when formulating conservation and management plans. However, care should be given to revive specific narratives and practices that encourage biodiversity friendly behaviors rather than destroy it (Etiendem et al. 2011; Holmes et al. 2017; Masius and Sprenger 2015). In Kibale, further surveys should inquire if local communities wish to implement their traditional knowledge in conservation, what knowledge they want to promote, and how they want to promote it (school education, agricultural program, etc.). Researchers, NGOs, biodiversity managers and local communities could jointly develop an innovative biodiversity conservation management strategy to conserve wildlife and human related knowledge.

\section{CONCLUSION}

We investigated wildlife, traditional, and spiritual related knowledge among villagers living adjacent to Kibale National Park, Uganda and identified links between local communities and natural elements which are not currently emphasized in biodiversity management. Helping to maintain, revive, and integrate orally transmitted narratives in biodiversity management may increase conservation effectiveness in a more coowned perspective. As Kibale became a center of primate vision tourism, a real exchange between biodiversity managers, tourists, and local communities could value and promote the links between humans and wildlife.

\section{ACKNOWLEDGEMENTS}

We are grateful to Uganda Wildlife Authority and Uganda National Council for Science and Technology for giving us the authorization to conduct this survey. We thank Great Ape Conservation Project and its co-director J.M Krief for hosting our research, our translator N. Kwezi, and Sebitoli Chimpanzee Project's field assistants. We also thank A. Basemera (Kogere foundation, Fort Portal) for discussions over spiritual beliefs. We are particularly grateful to respondents for their time and interests. We thank colleagues from Paris Diderot, Museum national 
d'Histoire naturelle (especially C. Friedberg), and McGill University for their worthy comments on our work. Field trips were funded by the MNHN/ATM 16, ANR JC-JC SAFAPE, GACP, Université Paris Diderot (Ecole doctorale EESC 382), Laboratoire des Dynamiques Sociales et Recomposition des Espaces and Société Francophone de Primatologie.

\section{REFERENCES}

Adams M, Infield M (2003) Who is on the gorillas payroll? Claims on tourist revenue from a Ugandan National Park. World Development 31: 177-190

Archabald K, Naughton-Treves L (2001) Tourism revenue-sharing around National Parks in Western Uganda: Early efforts to identify and reward local communities. Environnemental Conservation 28: 135- 149

Aroles S (2007) L'énigme des enfants-loups: Une certitude biologique mais un déni des archives. Publibook, Paris, France

Attuquayefio DKS, Gyampoh S (2010) The Boabeng-Fiema Monkey Sanctuary, Ghana: A case for blending traditional and introduced wildlife conservation systems. West African Journal of Applied Ecology 17: 1-10

Beattie JHM (1971) "Cutting Kinship" in Bunyoro. Ethnology 10: 211-214

Behrend H (2011) Resurrecting cannibals. The Catholic Church, witch-hunts, and the production of Pagans in Western Uganda. James Currey, Woodbridge, UK

Bennett NJ, Roth R, Klain SC, Chan KMA, Clark DA, Cullman G (2017) Mainstreaming the social sciences in conservation. Conservation Biology 31: 56-66

Berkes F (2004) Rethinking community-based conservation. Conservation Biology 18: 621-630

Bortolamiol S (2014) Interactions hommes chimpanzés - forêt. Approche spatiale et territoriale de la répartition des chimpanzés, des perceptions locales et de la gestion de la biodiversité (Sebitoli, parc national de Kibale, Ouganda). PhD Dissertation, Université Paris Diderot, Paris, France
Bortolamiol S, Cohen M, Jiguet F, Pennec F, Seguya A, Krief S (2016) Chimpanzee nonavoidance of hyper-proximity to humans. Journal of Wildlife Management 80: 924-934

Bortolamiol S, Cohen, Krief S (2017) Territoires protégés, humains et chimpanzés. Une lisière fluctuante dans le temps et l'espace. Annales de Géographie 716: 435-463

Brooks AC, Buss IO (1962) Past and present status of the elephant in Uganda. Journal of Wildlife Management 26: 38-50

Byers BA, Cunliffe RN, Hudak AT (2001) Linking the conservation of culture and nature: $A$ case study of sacred forests in Zimbabwe. Human Ecology 29: 187-218

Ceballos G, Ehrlich PR, Dirzo R (2017) Biological annihilation via the ongoing sixth mass extinction signaled by vertebrate population losses and declines. PNAS 114: E6089-E6096

Chapman CA, Chapman LJ, Kaufman L, Zanne $A E$ (1999) Potential causes of arrested succession in Kibale National Park, Uganda: Growth and mortality of seedlings. African Journal of Ecology 37: 81-92

Chapman CA, Lambert JE (2000) Habitat alteration and the conservation of african primates: Case study of Kibale National Park, Uganda. American Journal of Primatology 50: 169-185

Chapman CA, Bortolamiol S, Matsuda I, Omeja P, Paim F, Sengupta R, Valenta K (2018) Primate population dynamics: Variation in abundance over space and time. Biodiversity and Conservation 27: 1221-1238

Chrétien JP (1985) L'empire des Bacwezi. La construction d'un imaginaire géopolitique. Annales Economies, Sociétés, Civilisations 40: 1335-1377

Costa S, Casanova C, Sousa C, Lee P (2013) The good, the bad and the ugly: Perceptions of wildlife in Tombal (Guinea-Bissau, West Africa). Journal of Primatology 2: 110

Dagba BI, Sambe LN, Shomkegh SA (2013) Totemic beliefs and biodiversity conservation among the Tiv People of Benue State, Nigeria. Journal of Natural Sciences Research 3: 145-149 
De Merode E, Smith KH, Homewood K, Pettifor R, Rowcliffe M, Cowlishaw G (2007) The impact of armed conflict on protected area efficacy in Central Africa. Biology Letters 3: 299-301

Descola P (2005) Par-delà nature et culture. Gallimard, Paris, France

Doyle S (2007) The Cwezi-kubandwa debate: Gender, hegemony and pre-colonial religion in Bunyoro, Western Uganda. Africa 77: 559-581

Etiendem DN, Hens L, Pereboom Z (2011) Traditional knowledge systems and the conservation of cross river gorillas: $A$ case study of Bechati, Fossimondi, Besali, Cameroon. Ecology and Society 16: 22

Friedberg C (1997) Diversité, ordre et unité du vivant dans les savoirs populaires. Natures Sciences Sociétés 5: 5-17

Friedberg C (2014) Protéger les humains et les non-humains. Revue d'ethnoécologie. [http://ethnoecologie.revues.org/1875] Accessed 1 August 2017

Gadgil M, Berkes F, Folke C (1993) Indigenous knowledge for biodiversity conservation. Ambio 22: 151-156

Ghanashyam Niroula, Singh NB (2015) Religion and conservation: $A$ review of use and protection of sacred plants and animals in Nepal. Journal of Institute of Science and technology 20: 61-66

Gorjestani N (2004) Indigenous knowledge for development: Opportunities and challenges. In: Twarog S, Kapoor P (eds) Protecting and promoting traditional knowledge: Systems, national experiences and international dimensions. UNCTAD, New York and Geneva, pp. 265-271

Graham A (1973) The gardeners of Eden. Allen and Unwin, London, UK

Hamilton AC (1984) The quaternary history of African forests: Its relevance to conservation. African Journal of Ecology 19: 1-6

Hartter J (2010) Resource use and ecosystem services in a forest park landscape. Society and Natural Resources 23: 207-223

Hartter J, Ryan SJ (2010) Top-down or bottomup? Decentralization, natural resource management, and usufruct rights in the forests and wetlands of Western Uganda. Land Use Policy 27: 815-826
Hartter J, Ryan SJ, MacKenzie CA, Goldman A, Dowhaniuk N, Palace M et al. (2015) Now there is no land: A story of ethnic migration in a protected area landscape in Western Uganda. Population and Environment 36: 452-479

Hill CM, Webber A (2010) Perceptions of nonhuman primates in human-wildlife conflict scenarios. American Journal of Primatology 72: 919-924

Holmes G, Aneurin Smith T, Ward C (2017) Fantastic beasts and why to conserve them: Animals, magic and biodiversity conservation. Oryx: 52: 231-239

Infield M (2001) Cultural values: A forgotten strategy for building community support for protected areas in Africa. Conservation Biology 15: $800-802$

Johnstone SHH, Kasagama OK (1906) The Toro Agreement. Her Majesty's Government for the Uganda Protectorate, Fort George, UK

Kasagama KK, Lugard F (1891) The Treaty with Kasagama. British East African Company, Fort Edward, UK

Kipling R (1895) The second Jungle Book. Macmillan Publishers, New York, USA

Klepeis P, Orlowska IA, Kent EF, Cardelus CL, Scull P, Wassie Eshete A, Woods C (2016) Ethiopian Church Forests: A hybrid model of protection. Human Ecology 44: 715-730

Köhler A (2005) Of Apes and Men: Baka and Bantu attitudes to wildlife and the making of eco-goodies and baddies. Conservation and society 3: 407-435

Kohn E (2013) How forests think: Toward an anthropology beyond the Human. University of California Press, Berkeley, USA

Koponen J (1988) People and production in late precolonial Tanzania: History and structures. Scandinavian Institute of African Studies, Uppsala, Sweden

Krief S, Brunois-Pasina F (2017) L'interspécificité du pharmakôn dans le parc Kibale (Ouganda): Savoirs partagés entre humains et chimpanzés? In: Gutierrez Choquevilca AL (ed) Guérir/Tuer. Cahiers d'anthropologie sociale - L'Herne, Paris, pp. 112134

Krief S, Cibot M, Bortolamiol S, Seguya A, Krief JM, Masi S (2014) Wild chimpanzees on the edge: Nocturnal activities in croplands. PLOS ONE 9: e109925 
MacKay KJ, Campbell JM (2012) Tourisme durable innovateur en Ouganda. Touristes internationaux, réseaux nationaux et moyens d'existence locaux. Téoros 1. [http://teoros.revues.org/2026] Accessed 23 September 2016

MacKenzie CA (2012) Trenches like fences make good neighbours: Revenue sharing around Kibale National Park, Uganda. Journal for Nature Conservation 20: 92-100

MacKenzie CA, Ahabyona P (2012) Elephants in the garden: Financial and social costs of crop raiding. Ecological Economics 75: 72-82

MacKenzie CA, Salerno J, Hartter J, Chapman CA, Reyna R, Mwesigye Tumusiime D, Drake M (2017) Changing perceptions of protected area benefits and problems around Kibale National Park, Uganda. Journal of Environmental Management 200: 217-228

Masius P, Sprenger J (2015) A fairytale in question: Historical interactions between humans and wolves. White Horse Press, Cambridge, UK

Mbale A, Ogwal I (2015) Uganda's Tea Payments Profile. UN Capital Development Fund, New York, USA

Mgumia F, Oba G (2003) Potential role of sacred groves in biodiversity conservation in Tanzania. Environmental Conservation 30: 259265

MISR - Makerere University Institute for Social Research and Land tenure center of University of Wisconsin (1989) Settlement in forest reserves, game reserves and national parks in Uganda. University of Wisconsin-Madison, Madison, USA

Morris HF (1978) Annual departmental reports relating to Uganda, 1903 - 1961. Microform Academic, East Ardsley, UK

Mugisha AR, Jacobson SK (2004) Threat reduction assessment of conventional and community-based conservation approaches to managing protected areas in Uganda. Environmental Conservation 31: 233-241

Muhumuza M, Balkwill K (2013) Factors affecting the success of conserving biodiversity in National Parks: A review of case studies from Africa. International Journal of Biodiversity 2013: 1-20
Narat V, Pennec F, Ledo-Bisson L, Bokika Ngawolo JC, Dumez R, Krief S (2015) Bonobo conservation as a means for local development: An innovative local initiative of community-based conservation in the Democratic Republic of the Congo. Journal of Primatology 4: 2

Naughton-Treves L (1999) Whose animals? A history of property rights to wildlife in Toro, Western Uganda. Land Degradation and Development 10: 311-328

Ntiamoa-Baidu Y (2008) Indigenous beliefs and biodiversity conservation: The effectiveness of sacred groves, taboos and totems in Ghana for habitat and species conservation. Journal for the Study of Religion, Nature and Culture 2: 309-326

Nyanganji G, Fowler A, McNamara A, Sommer V (2010) Monkeys and Apes as animals and humans. Ethnoprimatology in Nigeria's Tabara region. In: Sommer V, Ross C (eds) Primates of Gashaka. Socioecology and conservation in Nigeria's biodiversity hotspot. Springer, New York, pp. 101-134

van Orsdol KG (1986) Agricultural encroachment in Uganda's Kibale Forest. Oryx 20: $115-117$

Pennec F, Wencelius J, Garine E, Raimond C, Bohbot H (2012) Flame. CNRS, Paris, France

Peterson D, Goodall J (1993) Visions of Caliban: On chimpanzees and people. Houghton Mifflin, Boston, USA

Republic of Uganda (2012) Uganda tourism sector situational assessment: Tourism reawakening. Uganda Ministry of Tourism, Wildlife and Heritage Bank, Kampala, Uganda

Republic of Uganda (1996) The Uganda Wildlife Act. Republic of Uganda, Kampala, Uganda

Reyes-Garcia V, Guèze $M$, Luz AC, PanequeGalvez J, Macia MJ, Orta-Martinez $M$ et al. (2013) Evidence of traditional knowledge loss among a contemporary indigenous society. The evolution of human behavior 34: 249-257

Rim-Rukeh A, Irerhievwie G, Agbozu IE (2013) Traditional beliefs and conservation of natural resources: Evidences from selected communities in Delta State, Nigeria. International Journal of Biodiversity and Conservation 5: 426-432 
Roscoe J (1968) The Banyankole. Cambridge University Press, Cambridge, UK

Rubongoya LT (2003) Naaho Nubo - The ways of our ancestors. Rüdiger Köppe, Cologne, Germany

Saj TL, Mather C, Sicotte P (2006) Traditional taboos in biological conservation: The case of Colobus vellerosus at the Boabeng-Fiema Monkey Sanctuary, Central Ghana. Social Science Information 45: 285-310

Schultz P (2011) Conservation means behavior. Conservation Biology 25: 1080-1083

Sousa J, Vicente L, Gippoliti S, Casanova C, Sousa C (2014) Local knowledge and perceptions of chimpanzees in Cantanhez National Park, Guinea Bissau. American Journal of Primatology 76: 122-134

Steinhart E (1977) Conflict and collaboration in Western Uganda. Princeton University Press, Princeton, USA

Steinhart $E$ (2011) The ways of the past are not all bad': Gender, poverty and power in the representation of the Bacwezi. Mawazo 10: 211

Struhsaker TT (1997) Ecology of an African rainforest: Logging in Kibale and the conflict between conservation and exploitation. University Press of Florida, Gainesville, USA
Tam KP, Lee SL, Chao MM (2013) Saving Mr. Nature: Anthropomorphism enhances connectedness to and protectiveness toward nature. Journal of Experimental Social Psychology 49: 514-521

Toro Agreement (1900) Uganda Protectorate. [http://nointervention.com/archive/Africa/Uganda/ British_Protectorate/toro_agreement_1900.htm] No intervention. Accessed 3 February 2016

Tumusiime MD, Vedeld P (2012) False promise or false premise? Using tourism revenue sharing to promote conservation and poverty reduction in Uganda. Conservation and Society 10: $15-28$

Uganda Vision 2040 (2013) National Planning Authority. Republic of Uganda, Kampala, Uganda

UWA - Uganda Wildlife Authority (2000) Revenue sharing around Protected Areas. UWA, Kampala, Uganda

Zelenski JM, Nisbet EK (2014) Happiness and feeling connected: The distinct role of nature relatedness. Environment and Behavior 46: 323

Zylstra MJ, Knight AT, Esler KJ, Le Grange LL (2014) Connectedness as a core conservation concern: An interdisciplinary review of theory and a call for practice. Springer Science Reviews 2: 119-143

Received: 05 February 2017

Accepted: 15 August 2018

Published: 07 September 2018 
Additional information 1: Social, spiritual and spatial variables statistical relationships (KW= Kruskal-Wallis, $M W U=$ Mann-Whitney), Sebitoli area, Kibale National Park, Uganda.

\begin{tabular}{|c|c|c|c|c|c|}
\hline & $\begin{array}{c}\text { Household distance } \\
\text { to forest edge } \\
\text { (meters) }\end{array}$ & $\begin{array}{c}\text { Village } \\
\text { residency } \\
\text { (3 categories) }\end{array}$ & $\begin{array}{c}\text { Tribe } \\
\text { (3 categories) }\end{array}$ & $\begin{array}{c}\text { Clan } \\
\text { (13 categories) }\end{array}$ & $\begin{array}{c}\text { Totem } \\
(13 \\
\text { categories }) \\
\end{array}$ \\
\hline $\begin{array}{c}\text { Tribe (3 } \\
\text { categories) }\end{array}$ & $\begin{aligned}(\mathrm{KW}) \mathrm{H} 2 & =6.258, \mathbf{p} . \\
\text { value } & =\mathbf{0 . 0 4 4}\end{aligned}$ & $\begin{array}{c}\text { (Fisher) } \mathrm{p} . \\
\text { value= } 0.004\end{array}$ & - & - & $\begin{array}{c}\text { (Fisher) } \mathrm{p} . \\
\text { value }=0.169\end{array}$ \\
\hline $\begin{array}{c}\text { Clan (13 } \\
\text { categories) }\end{array}$ & $\begin{array}{c}(\mathrm{KW}) \mathrm{H} 2=17.738, \mathrm{p} . \\
\text { value }=0.168\end{array}$ & $\begin{array}{c}\text { (Fisher) } p . \\
\text { value }=0.626\end{array}$ & $\begin{array}{c}\text { (Fisher) } p . \\
\text { value }=0.043\end{array}$ & - & - \\
\hline $\begin{array}{l}\text { Totem (13 } \\
\text { categories) }\end{array}$ & $\begin{array}{c}(\mathrm{KW}) \mathrm{H} 2=15.349, \mathrm{p} . \\
\text { value }=0.223\end{array}$ & $\begin{array}{c}\text { (Fisher) } p . \\
\text { value }=0.838\end{array}$ & $\begin{array}{c}\text { (Fisher) } p . \\
\text { value }=0.169\end{array}$ & $\begin{array}{c}\text { (Fisher) } \mathrm{p} . \\
\text { value }<0.0001\end{array}$ & - \\
\hline $\begin{array}{l}\text { Sum of wild } \\
\text { animal citation }\end{array}$ & $\begin{array}{c}\text { (Correlation - } \\
\text { Pearson) } R=-0.082, \\
\text { p. value }=0.666\end{array}$ & $\begin{array}{c}(\mathrm{KW}) \mathrm{H} 2= \\
3.338, \mathrm{p} . \\
\text { value }=0.188\end{array}$ & $\begin{array}{c}(\mathrm{KW}) \mathrm{H} 2= \\
2.357, \mathrm{p} . \\
\text { value }=0.308\end{array}$ & $\begin{array}{c}(\mathrm{KW}) \mathrm{H} 2= \\
16.783, \mathrm{p} . \\
\text { value= } 0.209\end{array}$ & $\begin{array}{c}(\mathrm{KW}) \mathrm{H} 2= \\
13.269, \mathrm{p} . \\
\text { value }=0.350\end{array}$ \\
\hline $\begin{array}{c}\text { Wild animal as } \\
\text { totem citation } \\
(\text { Yes/No) }\end{array}$ & $\begin{array}{c}(\mathrm{MWU}) \mathrm{U}=87.5, \mathrm{p} . \\
\text { value }=0.588\end{array}$ & $\begin{array}{l}\text { (Fisher) } p \\
\text { value }=1\end{array}$ & $\begin{array}{c}\text { (Fisher) } \mathrm{p} . \\
\text { value }=0.825\end{array}$ & $\begin{array}{c}\text { (Fisher) } p \text {. } \\
\text { value }<0.0001\end{array}$ & - \\
\hline $\begin{array}{c}\text { Humans } \\
\text { resemble } \\
\text { chimpanzees } \\
\text { citation (Yes/No) }\end{array}$ & $\begin{array}{c}(\mathrm{MWU}) \mathrm{U}=122, \mathrm{p} . \\
\text { value }=0.650\end{array}$ & $\begin{array}{c}\text { (Fisher) } p . \\
\text { value }=0.721\end{array}$ & $\begin{array}{c}\text { (Fisher) } p . \\
\text { value }=0.852\end{array}$ & $\begin{array}{c}\text { (Fisher) } p . \\
\text { value }=0.385\end{array}$ & $\begin{array}{c}\text { (Fisher) } p . \\
\text { value }=0.524\end{array}$ \\
\hline $\begin{array}{l}\text { Sum of medicinal } \\
\text { plant species } \\
\text { citation }\end{array}$ & $\begin{array}{c}\text { (Correlation }- \\
\text { Pearson) } R=0.002, \\
\text { p. value }=0.993\end{array}$ & $\begin{array}{c}(\mathrm{KW}) \mathrm{H} 2= \\
2.837 \\
\text { p. value }=0.242\end{array}$ & $\begin{array}{c}(\mathrm{KW}) \mathrm{H} 2= \\
1.691, \mathrm{p} . \\
\text { value }=0.429\end{array}$ & $\begin{array}{c}(\mathrm{KW}) \mathrm{H} 2= \\
12.387, \mathrm{p} . \\
\text { value }=0.496\end{array}$ & $\begin{array}{c}(\mathrm{KW}) \mathrm{H} 2= \\
11.444, \mathrm{p} . \\
\text { value }=0.491\end{array}$ \\
\hline $\begin{array}{c}\text { Sum of firewood } \\
\text { plant species } \\
\text { citation }\end{array}$ & $\begin{array}{c}\text { (Correlation }- \\
\text { Pearson) } R=-0.287, \\
\text { p. value }=0.124\end{array}$ & $\begin{array}{c}(\mathrm{KW}) \mathrm{H} 2= \\
6.649, \mathbf{p} . \\
\text { value }=\mathbf{0 . 0 3 6}\end{array}$ & $\begin{array}{c}(\mathrm{KW}) \mathrm{H} 2= \\
0.202, \mathrm{p} . \\
\text { value }=0.904\end{array}$ & $\begin{array}{c}(\mathrm{KW}) \mathrm{H} 2= \\
8.166, \mathrm{p} . \\
\text { value }=0.833\end{array}$ & $\begin{array}{c}(\mathrm{KW}) \mathrm{H} 2= \\
7.953, \mathrm{p} . \\
\text { value }=0.789\end{array}$ \\
\hline $\begin{array}{l}\text { Sum of timber } \\
\text { plant species } \\
\text { citation }\end{array}$ & $\begin{array}{c}\text { (Correlation }- \\
\text { Pearson) } R=-0.236, \\
\text { p. value }=0.209\end{array}$ & $\begin{array}{c}(\mathrm{KW}) \mathrm{H} 2= \\
2.329, \mathrm{p} . \\
\text { value }=0.312\end{array}$ & $\begin{array}{c}(\mathrm{KW}) \mathrm{H} 2= \\
6.796, \mathbf{p} . \\
\text { value= } \mathbf{0 . 0 3 3}\end{array}$ & $\begin{array}{c}(\mathrm{KW}) \mathrm{H} 2= \\
12.235, \mathrm{p} . \\
\text { value }=0.508\end{array}$ & $\begin{array}{c}(\mathrm{KW}) \mathrm{H} 2= \\
13.729, \mathrm{p} . \\
\text { value }=0.318\end{array}$ \\
\hline $\begin{array}{c}\text { Sum of other } \\
\text { plant species } \\
\text { citation }\end{array}$ & $\begin{array}{c}\text { (Correlation }- \\
\text { Pearson) } R=-0.131, \\
\text { p. value }=0.490\end{array}$ & $\begin{array}{c}(\mathrm{KW}) \mathrm{H} 2= \\
4.478, \mathrm{p} . \\
\text { value }=0.107\end{array}$ & $\begin{array}{c}(\mathrm{KW}) \mathrm{H} 2= \\
3.059, \mathrm{p} . \\
\text { value }=0.217\end{array}$ & $\begin{array}{c}(\mathrm{KW}) \mathrm{H} 2= \\
17.576, \mathrm{p} . \\
\text { value= } 0.174\end{array}$ & $\begin{array}{c}(\mathrm{KW}) \mathrm{H} 2= \\
17.599, \mathrm{p} . \\
\text { value= } 0.128\end{array}$ \\
\hline $\begin{array}{c}\text { Kaliisa citation } \\
\text { (Yes/No) }\end{array}$ & $\begin{array}{c}(\mathrm{MWU}) \mathrm{U}=78, \mathrm{p} . \\
\text { value }=0.268\end{array}$ & $\begin{array}{c}\text { (Fisher) } \mathbf{p .} \\
\text { value= } \mathbf{0 . 0 0 0 6}\end{array}$ & $\begin{array}{c}\text { (Fisher) } p . \\
\text { value }=0.095\end{array}$ & $\begin{array}{c}\text { (Fisher) } \mathrm{p} . \\
\text { value }=0.210\end{array}$ & $\begin{array}{c}\text { (Fisher) } p . \\
\text { value }=0.398\end{array}$ \\
\hline $\begin{array}{c}\text { Nyakakaikuru } \\
\text { citation (Yes/No) }\end{array}$ & $\begin{array}{c}(\mathrm{MWU}) \mathrm{U}=87.5, \mathrm{p} \\
\text { value }=0.756\end{array}$ & $\begin{array}{c}\text { (Fisher) } \mathbf{p .} \\
\text { value }=\mathbf{0 . 0 3 7}\end{array}$ & $\begin{array}{c}\text { (Fisher) } p . \\
\text { value }=0.561\end{array}$ & $\begin{array}{c}\text { (Fisher) } p . \\
\text { value }=0.718\end{array}$ & $\begin{array}{c}\text { (Fisher) } \mathrm{p} . \\
\text { value }=0.778\end{array}$ \\
\hline $\begin{array}{c}\text { Ebiigasaigasa } \\
\text { citation (Yes/No) }\end{array}$ & $\begin{array}{c}(\mathrm{MWU}) \mathrm{U}=114.5, \mathrm{p} . \\
\text { value }=0.672\end{array}$ & $\begin{array}{c}\text { (Fisher) } p . \\
\text { value }=0.089\end{array}$ & $\begin{array}{c}\text { (Fisher) } p . \\
\text { value }=0.289\end{array}$ & $\begin{array}{c}\text { (Fisher) } p . \\
\text { value }=0.382\end{array}$ & $\begin{array}{c}\text { (Fisher) } p . \\
\text { value }=0.624\end{array}$ \\
\hline $\begin{array}{l}\text { Rugamba citation } \\
\text { (Yes/No) }\end{array}$ & $\begin{array}{c}(\mathrm{MWU}) \mathrm{U}=98, \mathrm{p} . \\
\text { value }=0.413\end{array}$ & $\begin{array}{c}\text { (Fisher) } p . \\
\text { value }=0.429\end{array}$ & $\begin{array}{c}\text { (Fisher) } \mathrm{p} . \\
\text { value }=0.089\end{array}$ & $\begin{array}{c}\text { (Fisher) } p . \\
\text { value= } 0.491\end{array}$ & $\begin{array}{c}\text { (Fisher) } p . \\
\text { value }=0.434\end{array}$ \\
\hline $\begin{array}{l}\text { Sum of transient } \\
\text { spirit citation }\end{array}$ & $\begin{array}{c}\text { (Correlation }- \\
\text { Pearson) } R=-0.131, \\
\text { p. value }=0.490\end{array}$ & $\begin{array}{c}(\mathrm{KW}) \mathrm{H} 2= \\
11.340, \mathbf{p} . \\
\text { value= } \mathbf{0 . 0 0 3}\end{array}$ & $\begin{array}{c}(\mathrm{KW}) \mathrm{H} 2= \\
5.238, \mathrm{p} . \\
\text { value }=0.073\end{array}$ & $\begin{array}{c}(\mathrm{KW}) \mathrm{H} 2= \\
15.124, \mathrm{p} . \\
\text { value }=0.300\end{array}$ & $\begin{array}{c}(\mathrm{KW}) \mathrm{H} 2= \\
11.833, \mathrm{p} . \\
\text { value }=0.459\end{array}$ \\
\hline $\begin{array}{l}\text { Sum of fix spirit } \\
\text { citation }\end{array}$ & $\begin{array}{c}\text { (Correlation - } \\
\text { Pearson) } R=0.127, \\
\text { p. value }=0.505\end{array}$ & $\begin{array}{c}(\mathrm{KW}) \mathrm{H} 2= \\
2.522, \mathrm{p} . \\
\text { value }=0.283\end{array}$ & $\begin{array}{c}(\mathrm{KW}) \mathrm{H} 2= \\
4.812, \mathrm{p} . \\
\text { value }=0.090\end{array}$ & $\begin{array}{c}(\mathrm{KW}) \mathrm{H} 2= \\
12.789, \mathrm{p} . \\
\text { value }=0.464\end{array}$ & $\begin{array}{c}(\mathrm{KW}) \mathrm{H} 2= \\
13.689, \mathrm{p} . \\
\text { value= } 0.321\end{array}$ \\
\hline $\begin{array}{l}\text { Sum of overall } \\
\text { spirit citation }\end{array}$ & $\begin{array}{c}\text { (Correlation - } \\
\text { Pearson) } R=-0.089, \\
\text { p. value }=0.639\end{array}$ & $\begin{array}{c}(\mathrm{KW}) \mathrm{H} 2= \\
7.137, \mathbf{p} . \\
\text { value= } \mathbf{0 . 0 2 8}\end{array}$ & $\begin{array}{c}(\mathrm{KW}) \mathrm{H} 2= \\
3.771, \mathrm{p} . \\
\text { value }=0.152\end{array}$ & $\begin{array}{c}(\mathrm{KW}) \mathrm{H} 2= \\
15.142, \mathrm{p} . \\
\text { value= } 0.299\end{array}$ & $\begin{array}{c}(\mathrm{KW}) \mathrm{H} 2= \\
10.864, \mathrm{p} . \\
\text { value= } 0.541\end{array}$ \\
\hline
\end{tabular}


Additional information 2a: Medicinal plant species used by respondents $\left(N_{i}=30\right)$, Sebitoli area, Kibale National Park, Uganda.

\begin{tabular}{|c|c|c|c|c|c|}
\hline Medicinal plant species & $\begin{array}{c}\text { Vernacular } \\
\text { Common Name }\end{array}$ & $\begin{array}{l}\text { Citation in } \\
\text { Kihingami }\end{array}$ & $\begin{array}{l}\text { Citation in } \\
\text { Nyakabingo }\end{array}$ & $\begin{array}{l}\text { Citation in } \\
\text { Sebitoli }\end{array}$ & Total \\
\hline Acanthus pubescens & Amatojo & 1 & 0 & 1 & 2 \\
\hline Aframomum angustifolium & Amatehe & 0 & 0 & 1 & 1 \\
\hline Albizia coriaria & Omusisa & 0 & 1 & 0 & 1 \\
\hline Aloe vera & Enkokorutanga & 3 & 1 & 0 & 4 \\
\hline Artocarpus heterophyllus & Jack fruit & 1 & 1 & 0 & 2 \\
\hline Bidens pilosa & Nyabarasana & 2 & 4 & 0 & 6 \\
\hline Blighia unijugata & Omwataibale & 0 & 1 & 0 & 1 \\
\hline Brachiaria decumbens & Ejubwa & 0 & 0 & 1 & 1 \\
\hline Camellia sinensis & Amajani & 1 & 0 & 0 & 1 \\
\hline Carica papaya & Pawpaw & 0 & 1 & 0 & 1 \\
\hline Cassia didymobotrya & Omuchora & 1 & 0 & 0 & 1 \\
\hline Catha edulis & Amairungi & 0 & 0 & 1 & 1 \\
\hline Conyza floribunda & Ekinyansambu & 0 & 0 & 1 & 1 \\
\hline Crassocephalum montuosum & Ekiinami & 0 & 1 & 0 & 1 \\
\hline Cymbopogon citratus & Kalifuha & 0 & 1 & 0 & 1 \\
\hline Cyphomandra betacea & Ekidodoima & 0 & 1 & 1 & 2 \\
\hline Dichrocephala integrifolia & Omubuza & 0 & 1 & 0 & 1 \\
\hline Dioscorea sp. & Ebinyongo & 0 & 1 & 0 & 1 \\
\hline Diospyros abyssinica & Omuhoko & 0 & 1 & 0 & 1 \\
\hline Dracaena fragrans & Omugorogoro & 2 & 0 & 0 & 2 \\
\hline Erlangea cordifolia & Entooma & 0 & 1 & 0 & 1 \\
\hline Erlangea tomentosa & Ekitokotoko & 0 & 1 & 2 & 3 \\
\hline Guizotia scabra & Ekiterankuba & 1 & 0 & 0 & 1 \\
\hline Hoslundia opposita & Orutotoimya & 1 & 0 & 1 & 2 \\
\hline Ipomoea batatas & Enkoora & 0 & 1 & 0 & 1 \\
\hline Kalanchoe pinnata & Enyondo & 1 & 1 & 0 & 2 \\
\hline Lantana trifolia & Omusekera & 0 & 1 & 1 & 2 \\
\hline Macaranga sp. & Omukoko & 1 & 0 & 1 & 2 \\
\hline Maesa lanceolata & Omuhangabagenzi & 0 & 0 & 1 & 1 \\
\hline Mangifera indica & Omuyembe & 0 & 1 & 0 & 1 \\
\hline Markhamia lutea & Omusambya & 0 & 1 & 0 & 1 \\
\hline Momordica foetida & Omwihura & 0 & 0 & 2 & 2 \\
\hline Mondia whitei & Omurondwa & 0 & 0 & 1 & 1 \\
\hline Musa sp. & Bitooke & 0 & 1 & 0 & 1 \\
\hline Ocimum gratissimum & Ekijaaja & 5 & 2 & 1 & 8 \\
\hline Ocimum rothii & Omweya & 2 & 1 & 2 & 5 \\
\hline Persea americana & Avocado & 0 & 1 & 0 & 1 \\
\hline Plectranthus barbatus & Ekinyamunsunga & 1 & 0 & 0 & 1 \\
\hline Prunus africana & Engote & 2 & 1 & 1 & 4 \\
\hline Psidium guajava & Amapera & 1 & 2 & 1 & 4 \\
\hline Ricinus communis & Ebisogasoga & 0 & 3 & 0 & 3 \\
\hline Sonchus oleraceus & Ekizimyamurro & 0 & 1 & 0 & 1 \\
\hline Spathodea nilotica & Omunyarra & 0 & 0 & 1 & 1 \\
\hline Tagetes minuta & Omukazimurofu & 0 & 1 & 1 & 2 \\
\hline Turraea africana & Embahira & 0 & 2 & 0 & 2 \\
\hline Vanilla planifolia & Vanilla & 0 & 1 & 0 & 1 \\
\hline Vernonia amygdalina & Ekibirizi & 5 & 5 & 3 & 13 \\
\hline Zanthoxylum gilletii & Mutatembwa & 0 & 0 & 1 & 1 \\
\hline Species number & & 17 & 31 & 21 & 48 \\
\hline Total citation & & 31 & 43 & 26 & 100 \\
\hline
\end{tabular}


Additional information 2b: Firewood plant species used by respondents $\left(N_{i}=30\right)$, Sebitoli area, Kibale National Park, Uganda.

\begin{tabular}{|l|l|c|c|c|c|}
\hline \multicolumn{1}{|c|}{ Firewood plant species } & $\begin{array}{c}\text { Vernacular } \\
\text { Common Name }\end{array}$ & $\begin{array}{c}\text { Citation in } \\
\text { Kihingami }\end{array}$ & $\begin{array}{c}\text { Citation in } \\
\text { Nyakabingo }\end{array}$ & $\begin{array}{c}\text { Citation in } \\
\text { Sebitoli }\end{array}$ & Total \\
\hline Acanthus pubescens & Amatojo & 1 & 0 & 1 & $\mathbf{2}$ \\
\hline Albizia grandibracteata & Omurungo & 0 & 4 & 0 & $\mathbf{4}$ \\
\hline Allophylus sp. & Kabiriti & 1 & 0 & 0 & $\mathbf{1}$ \\
\hline Blighia unijugata & Omwataibale & 1 & 1 & 0 & $\mathbf{2}$ \\
\hline Bridelia micrantha & Omubaragaza & 1 & 4 & 1 & $\mathbf{6}$ \\
\hline Eucalyptus sp. & Kalitesi & 4 & 5 & 5 & $\mathbf{1 4}$ \\
\hline Fagara macrophylla & Omubakampungu & 0 & 1 & 0 & $\mathbf{1}$ \\
\hline Ficus natalensis & Omutoma & 0 & 2 & 0 & $\mathbf{2}$ \\
\hline Hoslundia opposita & Orutotoimya & 0 & 1 & 0 & $\mathbf{1}$ \\
\hline Macaranga sp. & Omukoko & 1 & 0 & 2 & $\mathbf{3}$ \\
\hline Markhamia lutea & Omusambya & 0 & 2 & 1 & $\mathbf{3}$ \\
\hline Mytrogina sp. & Omuniamaizi & 1 & 0 & 1 & $\mathbf{2}$ \\
\hline Newtonia butchananii & Omuchenche & 1 & 0 & 0 & $\mathbf{1}$ \\
\hline Olea sp. & Omusoko & 0 & 1 & 0 & $\mathbf{1}$ \\
\hline Parinari excelsa & Amabura & 1 & 0 & 0 & $\mathbf{1}$ \\
\hline Pennisetum purpureum & Omabingo & 1 & 0 & 0 & $\mathbf{1}$ \\
\hline Polyscias fulva & Omujugantara & 1 & 1 & 0 & $\mathbf{2}$ \\
\hline Prunus africana & Engote & 3 & 0 & 1 & $\mathbf{4}$ \\
\hline Psidium guajava & Amapera & 2 & 1 & 1 & $\mathbf{4}$ \\
\hline Ricinus communis & Ebisogasoga & 1 & 3 & 0 & $\mathbf{4}$ \\
\hline Sapium sapindas & Omusasa & 1 & 1 & 0 & $\mathbf{2}$ \\
\hline Sesbania sesban & Emibimba & 2 & 2 & 1 & $\mathbf{5}$ \\
\hline Vernonia amygdalina & Ekibirizi & 2 & 0 & 0 & $\mathbf{2}$ \\
\hline Species number & & $\mathbf{1 7}$ & $\mathbf{1 4}$ & $\mathbf{9}$ & $\mathbf{2 3}$ \\
\hline Total citation & & $\mathbf{2 9}$ & $\mathbf{1 4}$ & $\mathbf{6 8}$ \\
\hline
\end{tabular}




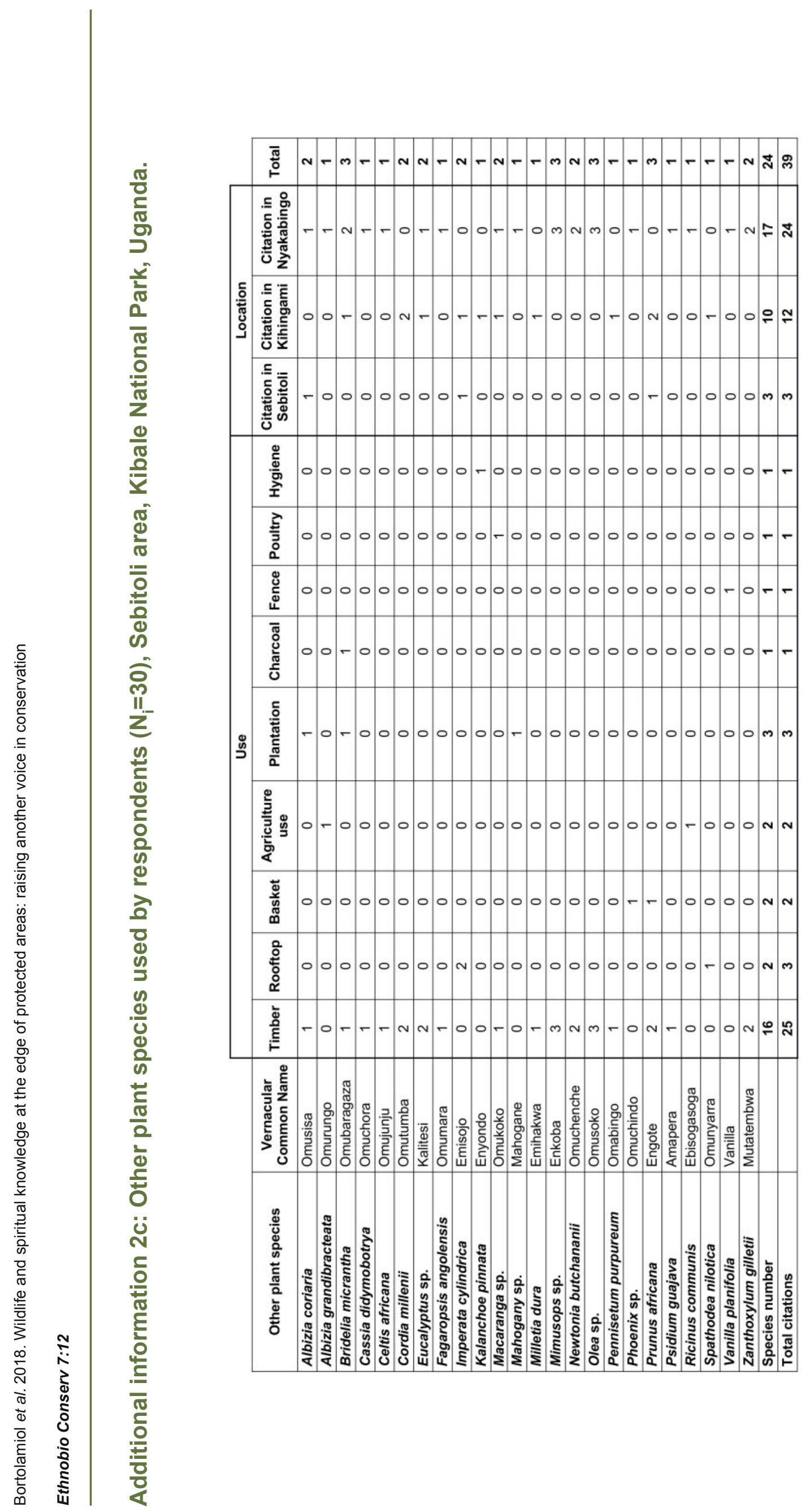


Additional information 3: Description of chimpanzee behavior while crop feeding, Sebitoli area, Kibale National Park, Uganda.

A villager described how two chimpanzees entered the field by one access point and as the owner of the field was trying to scare them away, two other chimpanzees entered by the opposite side of the field to obtain maize (entrance points were $90 \mathrm{~m}$ apart) and suggested this was an intentional strategy. This villager described having to go back and forth several times between the different points of the field to scare both groups away.

Additional information 4: Narrative told by a mother and her daughter evoking a distant subsidiary relationship between humans and chimpanzees, Sebitoli area, Kibale National Park, Uganda.

Long time, there used to be a family, the man and his wife. During that time, they had to pay taxes but they wanted to avoid paying them since they didn't have the money and the conditions were difficult. So they decided to go inside the forest. After reaching the forest, they stayed there for a long time and they gave birth. The kids they gave birth had hairs all over the body because of staying in the forest a lot, the food they found there and the conditions of the forest. They had kids and those kids also had kids. They happened to stay in the forest for their entire life. They accumulated, they became many and the population was extremely high. They ended up being called chimpanzees and that is how they came to exist. 


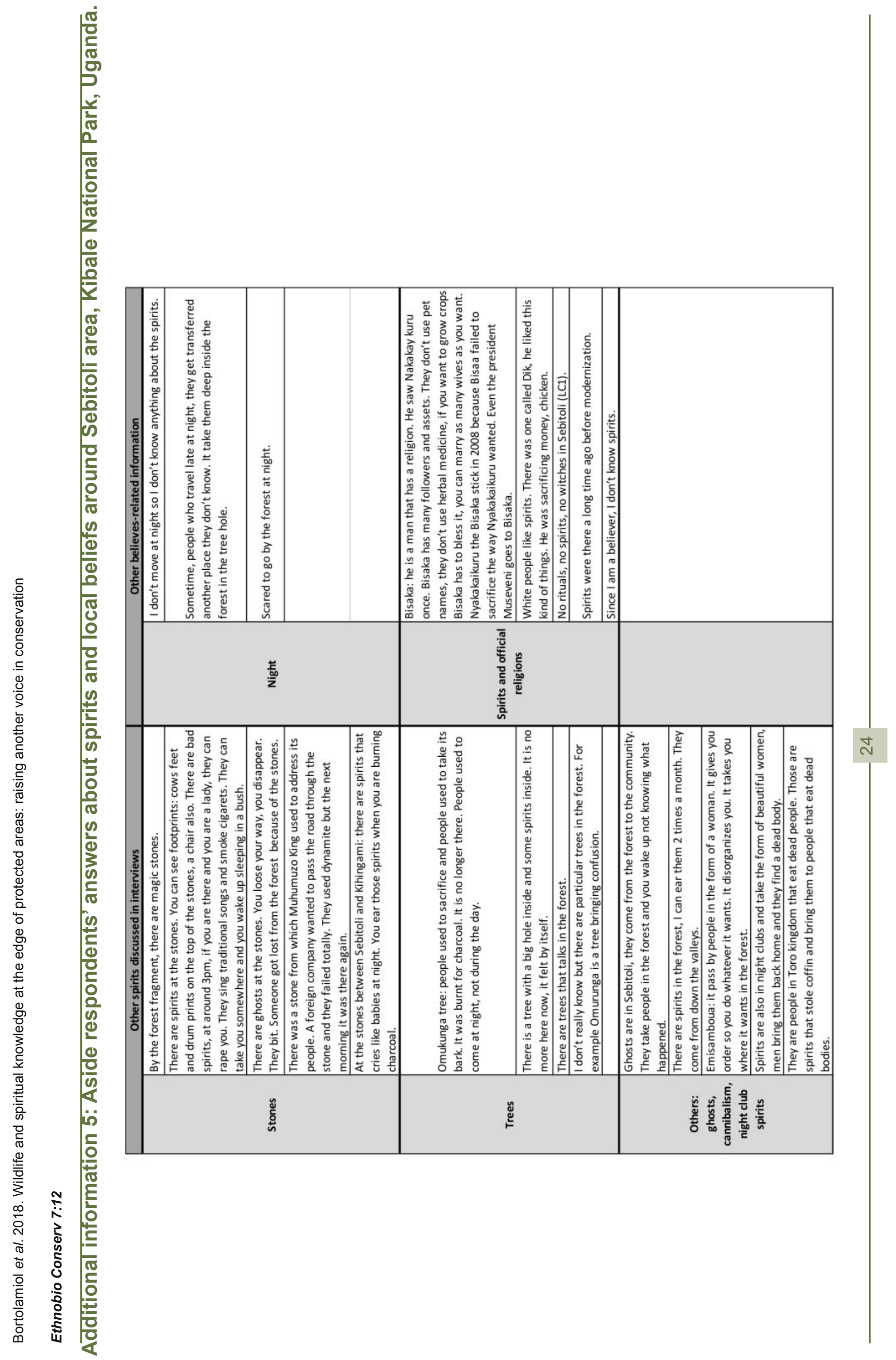


Additional information 6a: Stories told about Rugamba tree by one person living in Sebitoli village (identified by four of the people that we interviewed as being particularly knowledgeable about Rugamba tree) and tree villagers, Kibale National Park, Uganda.

"It is very different from other trees; it was the only one like that. Only people who were initiated could tell you more, it was secret. People used to sacrifice there, to that tree, and asked it services. They also throw money and coins to that tree.

In 1958, the road constructors wanted to bypass the road besides that tree so they wanted it off. I went to enquire about what happened and they said it refused to be cut. They tried to eliminate it but in vain, even two machine drivers died from there. That is when they proved that it had spirits, may be evil spirits.

It used to cry when you tried to cut it and it cried blood when they cut it. They finally used dynamite, it is meant for busting stones and it finally worked. The workers displaced it from where it was. At the time, local people around here were sent away and they were not allowed to be at the site when they eliminated that tree. After it was pushed far away, people were allowed to be around. After three days, a young one came out and was produced from that main big tree. Up to now, it is still there. People used to sacrifice [money, poultry] for that tree. It used to talk like a person. When they were trying to cut it, an old woman came out of the tree. The Italians [The constructors] wanted to photo shoot it and it disappeared. It was in form of an old woman. She was just shooting and jumping from the tree. It is not possible that we know what it used to talk. People who were involved in eliminating the tree are the ones who know what it said since local people were never allowed to be around.

Now people are informed, they no longer believe in such spirits. People of long time are the ones who got involved in such spirits. Right now, it is not possible that people still sacrifice because the young generation is informed about religion; they are not interested in such evil spirits. They no longer believe in spirits of long times. The same applies to me, when I was young, I believed in it."

Three villagers said that the tree was talking while being cut but each informer had a different version of this speech: (1) the tree asked why it was being cut; (2) the tree asked not to be cut as well as its suckers ("Don't cut me or my child"); (3) the tree asked to be cut instead of its suckers, as the Engote tree. 
Additional information 6b: Story told about Engote tree by one person living in Sebitoli village (the same person identified by four of the people that we interviewed as being particularly knowledgeable about Rugamba tree), Kibale National Park, Uganda.

"There are different tree species around. I can tell you about Engote tree, where a bus crashed seven years ago. People wanted to cut that tree. They cut it all around but it failed to fall. The axe went through but it failed to fall down. It asked people to sacrifice two heads of people. Then a person disappeared from that area. After some good time, not very long, the tree felt down. Few weeks after falling down, a bus accident occurred. Almost eight people died, including white people who were in that Kalita bus [name of national company]. They were travelling from Kampala to Fort Portal. People who know think the tree and its spirit sacrificed for itself, even thought it was already cut. There are very weird trees with those kind of spirits in the area."

Additional information 6c: Story told about Engote tree by one person living in Kihingami village, Kibale National Park, Uganda.

"There was another tree as heading to the forest fragment outside the park. The Mukwano employees [Tea company] used to cut it, and the next day they would find it there, standing. They did it several times and even made sacrifice (goats, bloody animals) to please the tree spirit. After scarifying, they tried to cut it again and they found it standing again the next day. So next time they bought a bulldozer. They finally managed to apprut it. After some good time, a Kalita bus [name of a national company] got an accident at the exact same place where Engote used to be and many people died. So people think that Engote spirit sacrified for itself." 